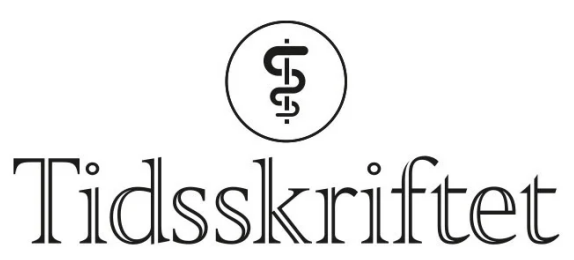

DEN NORSKE LEGEFORENING

\title{
Multiple arterielle tromboembolier etter covid-19
}

KORT KASUISTIKK

\section{MATTHEW SPREADBURY}

mattspreadbury@gmail.com

Karkirurgisk avdeling

Haukeland universitetssjukehus

Matthew Spreadbury er LIS3-lege.

Forfatteren har fylt ut ICMJE-skjemaet og oppgir ingen interessekonflikter.

\section{ESPEN GUBBERUD}

Karkirurgisk avdeling

Haukeland universitetssjukehus

Espen Gubberud er avdelingsjef og overlege.

Forfatteren har fylt ut ICMJE-skjemaet og oppgir ingen interessekonflikter.

\section{HENRIK HALVORSEN}

Karkirurgisk avdeling

Haukeland universitetssjukehus

Henrik Halvorsen er overlege.

Forfatteren har fylt ut ICMJE-skjemaet og oppgir ingen interessekonflikter.

\section{JON BJØRKUM}

Radiologisk avdeling

Haukeland universitetssjukehus

Jon Bjørkum er LIS2-lege.

Forfatteren har fylt ut ICMJE-skjemaet og oppgir ingen interessekonflikter.

\section{ANTJE BUTTER}

Karkirurgisk avdeling

Haukeland universitetssjukehus

Antje Butter er ph.d. og LIS3-lege.

Forfatteren har fylt ut ICMJE-skjemaet og oppgir ingen interessekonflikter.

\section{En middelaldrende mann fikk påvist tromboembolisk sykdom bare uker etter gjennomgått covid-19. Omfanget var mer omfattende enn man kunne forventet gitt pasientens}




\section{risikofaktorer.}

En mann i 5o-årene ble innlagt på lokalsykehus på grunn av smerter, avblekning, kuldefornemmelse og nedsatt sensibilitet i begge underekstremiteter. Tre uker tidligere hadde han gjennomgått covid-19 med feber, sår hals, brystsmerter og hoste, men ingen tung pust. Etter sykdom og karantene hadde han vært i full jobb i en uke.

Pasienten hadde hyperkolesterolemi og ble behandlet med perkutan koronar intervensjon for et hjerteinfarkt sju år tidligere. Etter dette hadde han sluttet å røyke og var i god fysisk form.

PCR-test for covid-19 ved innkomst var negativ, og pasienten hadde ingen respiratoriske symptomer. CT-angiografi viste manglende kontrastfylling fra begge aa. poplitea i kneleddsspalten (figur 1). Han hadde også okklusjoner distalt, men stedvis kontrastfylling av leggarterier, forenlig med tromboser i begge underekstremiteter. Pasienten fikk 5000 IE dalteparin og ble deretter overflyttet til et regionssykehus.

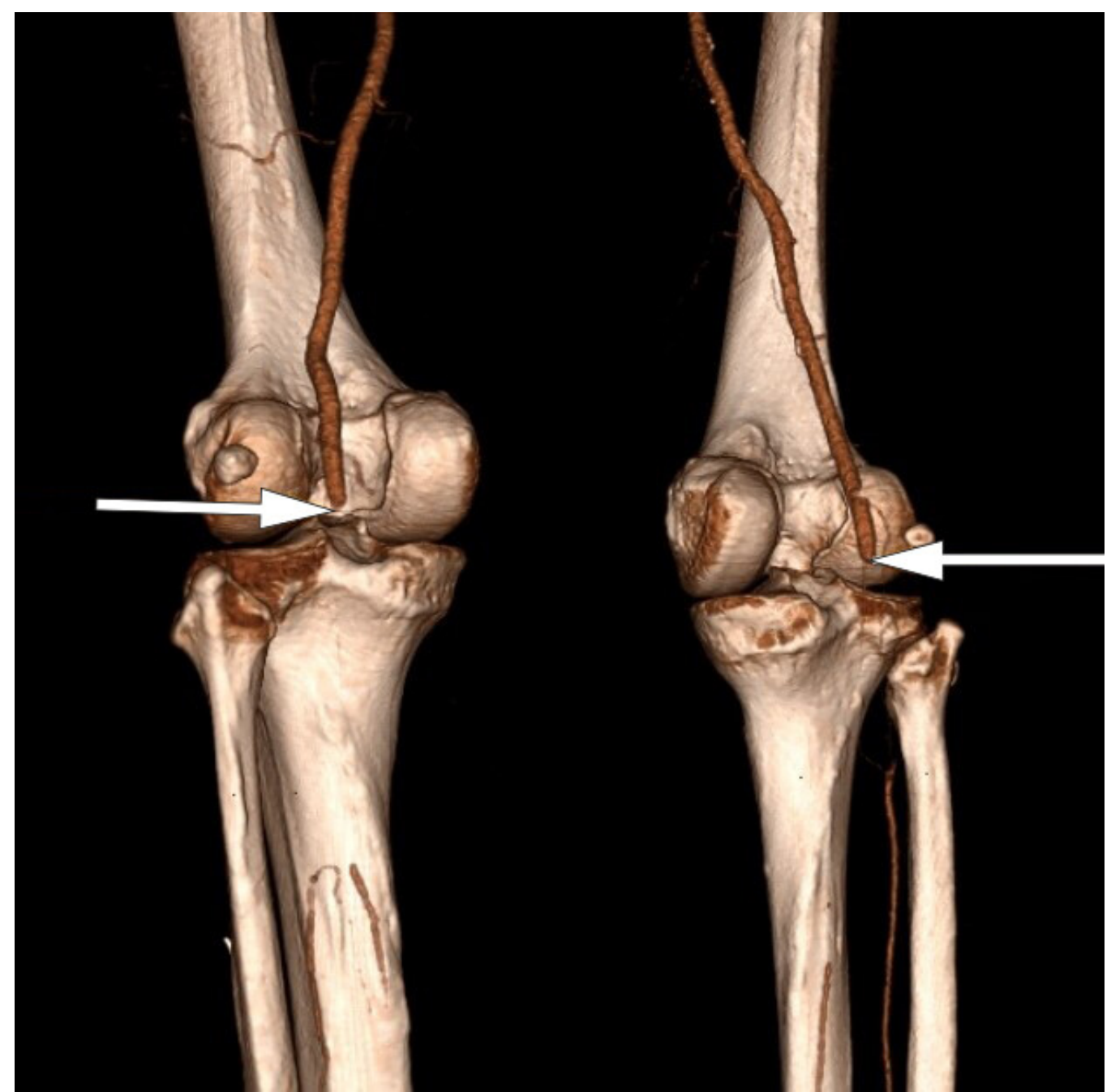

Figur 1 CT-angiografi viser bilateral full stopp i arteriell sirkulasjon i a. poplitea.

Ved ankomst regionssykehuset var pasienten respiratorisk og sirkulatorisk stabil. Venstre underekstremitet hadde kliniske tegn på akutt iskemi med smerte og redusert sensibilitet, men bevart motorikk. Høyre underekstremitet hadde i løpet av dagen blitt gradvis bedre med bevart sensibilitet og motorikk, men var fortsatt kald perifert. Pasienten ble operert i generell narkose med trombektomi av bilaterale aa. poplitea og leggarterier. Postoperativt var begge ben velsirkulerte.

Etter noen timer ble høyre fot igjen kjølig, smertefull og uten dopplersignal i fotarterier. Pasienten ble derfor reoperert. Det ble på ny gjort utrenskning av leggarterier med funn av rikelig med trombemasser. 
Postoperativt var det tilbakegang av alle symptomer i bena, men pasientens oksygenmetning var påfallende lav med $\mathrm{SpO}_{2}$ på 94,5\% (referanseområde > $99 \%$ ). Blodgass tatt mens pasienten fikk $3 \mathrm{~L} \mathrm{O} 2$ via nesekateter viste $\mathrm{pH}_{7,47}(7,36-7,44), \mathrm{pCO}_{2} 4,5 \mathrm{kPa}$ $(4,5-6,1)$ og pO2 8,9 kPa $(>9,6)$. Det ble utført CT toraks-angiografi, som viste flere lungeembolier i begge underlapper samt mattglassforandringer typiske for gjennomgått covid-19-pneumoni (figur 2). I tillegg så man en $7 \mathrm{~mm}$ stor pendulerende trombe distalt i aortabuen (figur 3). Dalteparin ble økt til 10 ooo IE $\times 2$, og pasienten fikk ikke-invasiv respirasjonsstøtte på intensivavdeling.

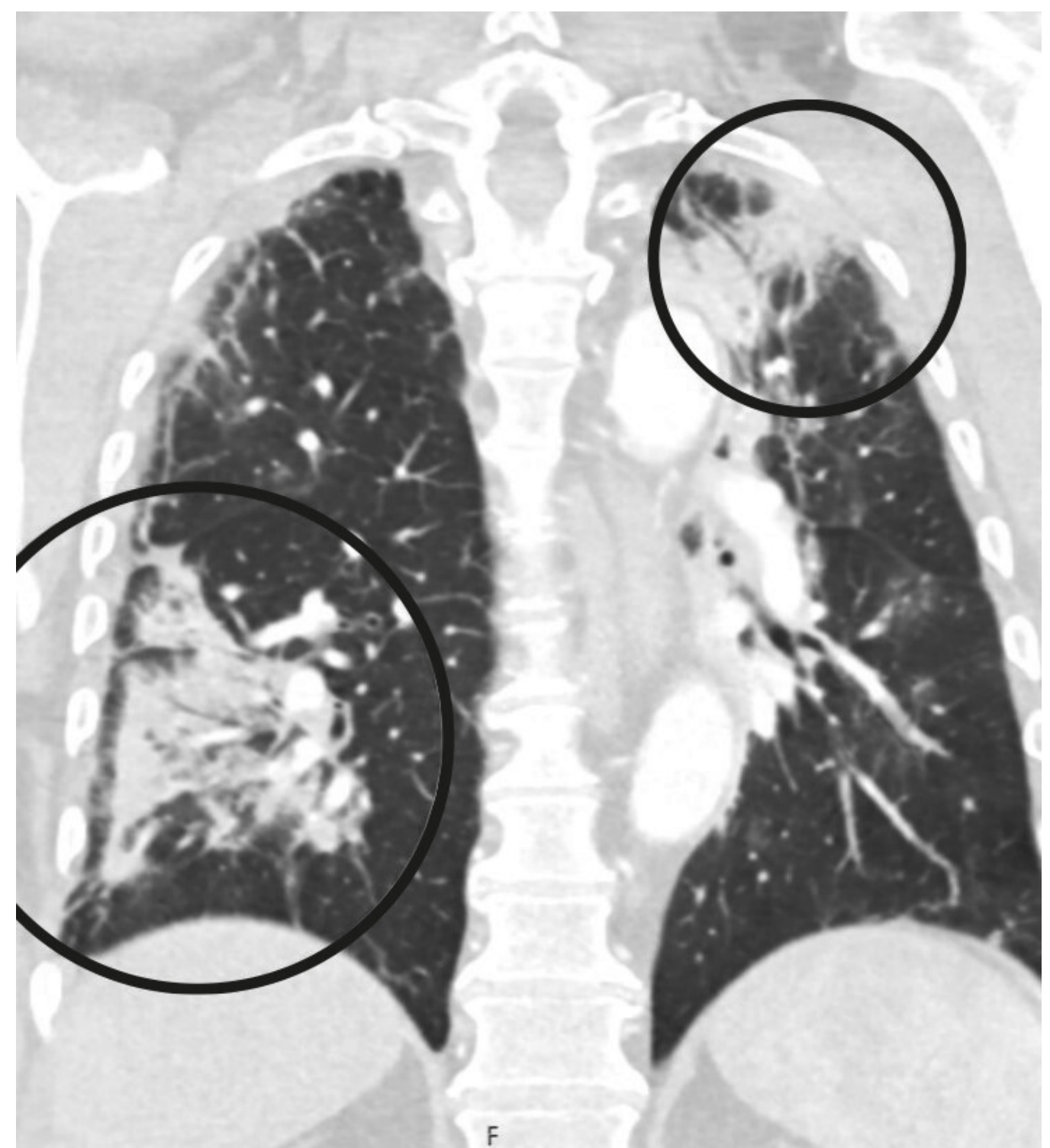

Figur 2 Lungefortetninger med delvis konsolidering og mattglasspreg. 


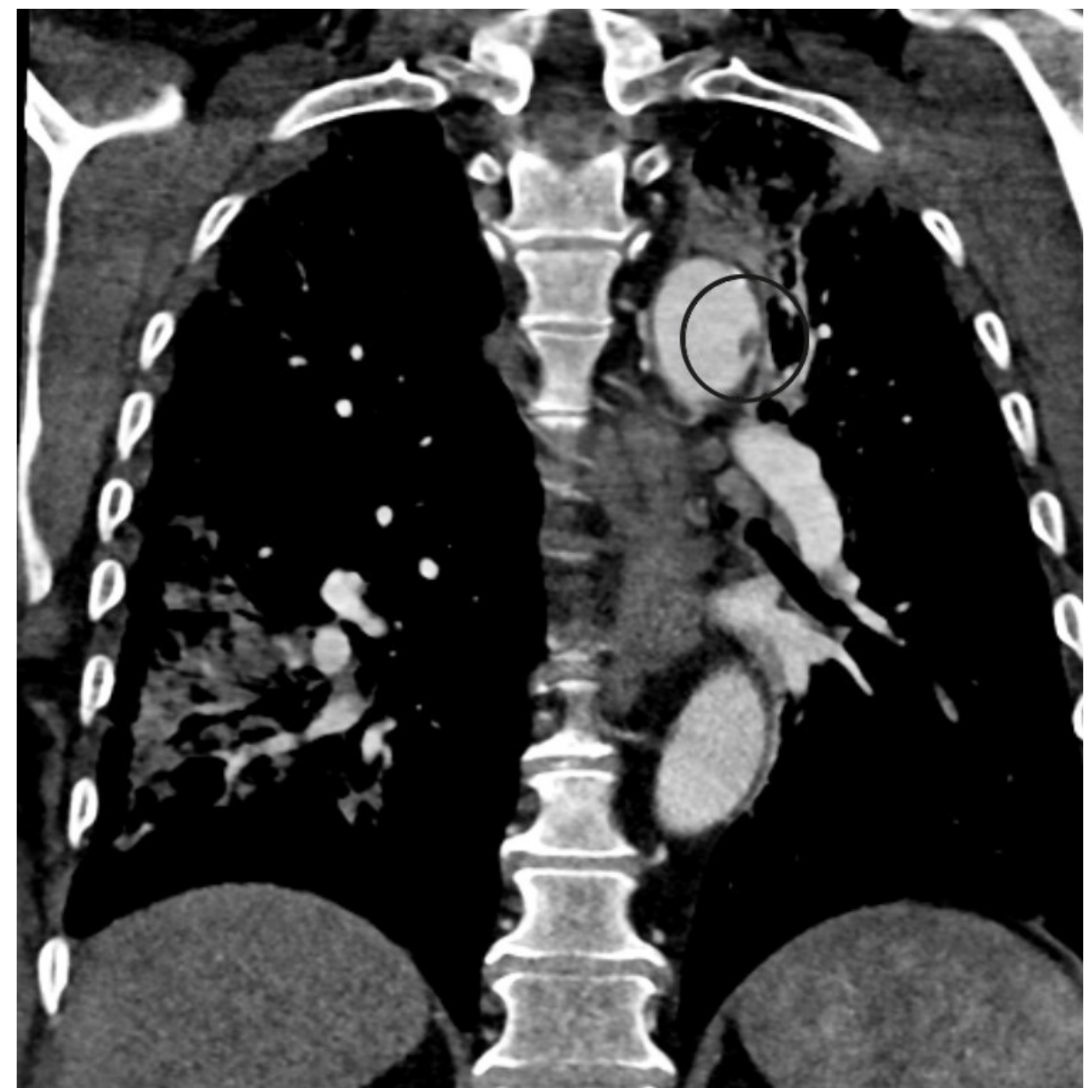

Figur 3 Trombe i aortabuen.

Ved ekkokardiografi to dager senere ble det påvist en trombe med diameter på $1 \mathrm{~cm}$ i apeks av hjertet. Det var lett apikal hypokinesi, men ellers god kontraktilitet av venstre ventrikkel. Det ble ikke påvist hjertearytmi eller tegn til gjennomgått hjerteinfarkt. En hematologisk utredning, med tanke på antifosfolipid syndrom (inkludert testing av lupus antikoagulant, anti-cardiolipin-antistoffer og beta-2 glycoprotein I antistoff) viste ingen patologiske funn som kunne forklare embolisering. Normale trombocytter og lett forhøyet fibrinogen på 5,3 g/L (1,9-4) og D-dimer på 14,8 mg/L (<0,57) var som forventet ved trombose. Man konkluderte med at pasienten var tilstrekkelig behandlet med dalteparin 10 ooo $\mathrm{E} \times 2$, at pasienten skulle følges opp av hematolog og etter hvert skifte behandling til DOAK eller marevan. Ni dager etter innkomst ble pasienten skrevet ut i velbefinnende med normal gangfunksjon. Han ble henvist til videre oppfølging ved medisinsk avdeling på lokalsykehuset.

\section{Diskusjon}

Flere internasjonale studier har dokumentert at akutte infeksjoner med covid-19 kan medføre $\emptyset \mathrm{kt}$ risiko for tromboemboliske hendelser (1-4). Vår pasient hadde flere risikofaktorer for tromboemboliske hendelser. Man kan likevel ikke utelukke covid-19 som utløsende faktor. Mye tyder på at covid-19 infiltrerer endotelet og igangsetter en karskadereaksjon, som fører til økt tromboembolirisiko $(\underline{2}, 4$.). Pasienter med covid-19 har dessuten økt plasmaviskositet som også bidrar til hyperkoagulabilitet (5). Dette kan forklare at den aktuelle pasienten hadde tromber på seks ulike anatomiske steder, som foruten covid-19 vanskelig lar seg forklare av én enkel årsak. En kan mistenke at lokal 
karskadereaksjon og hyperkoagulabilitet etter covid-19 førte til trombedannelse i hjertet og aortabuen hos pasienten. Disse har sannsynligvis senere embolisert til begge underekstremiteter.

Mange pasienter gjennomgår et mildt sykdomsforløp av covid-19, og må derfor ikke behandles på sykehus. Det øker risikoen for at eventuelle emboliske komplikasjoner ikke fanges opp og dermed underrapporteres. Det er usikkert om man bør gi profylaktisk platehemming eller antikoagulasjon hos alle pasienter som har gjennomgått en symptomatisk SARS-CoV-2-infeksjon.

International Society for Thrombosis \& Haemostasis har nylig godkjent WHOretnlingslinjene (므) som anbefaler at alle hospitaliserte covid-19-pasienter skal observeres med tanke på forekomst av tromboemboli, inkludert slag, dyp venetrombose, lungeemboli og hjerteinfarkt, og få standard tromboseprofylakse mot venøs tromboemboli (므). For tiden pågår kliniske studier av hva som er optimal dosering av antikoagulerende medikamenter ved covid-19, og retningslinjene vil oppdateres fortløpende (.7.).

Når det gjelder bruk av platehemmere, har man i USA begynt å behandle covid-19-pasienter «off label» med profylaktisk lavdose acetylsalisylsyre (ㅁ). Andre europeiske land, som for eksempel Tyskland (9.), avstår fra profylaktisk bruk av acetylsalisylsyre pga. økt blødningsrisiko og manglende evidens så langt.

Av særlig interesse for det karkirurgiske miljøet i Norge er at covid-19-pasienter har opptil $25 \% ø k t$ risiko for spontan retrombosering etter primær revaskularisering (10). Dette sammenfaller med vår erfaring. I en studie av 674 covid-19-pasienter i Nord-Italia som ble operert for akutt kritisk iskemi, ble det observert at pasientene som i tillegg fikk aggressiv antikoagulasjon (med kontinuerlig heparininfusjon) sjeldnere fikk retrombosering $(\underline{11}, \underline{12})$.

Denne kasuistikken, og stadig nye publikasjoner, har gjort oss oppmerksomme på sammenhengen mellom covid-19 og økt fare for alvorlige arterielle og venøse tromboemboliske hendelser. En karkirurgisk vurdering bør gjøres tidlig i forløpet ved klinisk mistanke om tromboemboli. Det direkte årsaksforholdet i overnevnte kasuistikk, kan ikke sikkert fastslås. Det var likevel en dramatisk og høyst utypisk sykdomspresentasjon gitt pasientens øvrige risikoprofil.

Pasienten har samtykket til at artikkelen blir publisert.

Artikkelen er fagfellevurdert.

\section{LITTERATUR}

1. Engelmann B, Massberg S. Thrombosis as an intravascular effector of innate immunity. Nat Rev Immunol 2013; 13:34-45. [PubMed][CrossRef]

2. Miesbach W, Makris M. COVID-19: Coagulopathy, risk of thrombosis, and the rationale for anticoagulation. Clin Appl Thromb Hemost 2020; 26: 1076029620938149. [PubMed][CrossRef]

3. Poyiadji N, Cormier P, Patel PY et al. Acute pulmonary embolism and COVID-19. Radiology 2020; 297: E335-8. [PubMed][CrossRef]

4. Kvåle R, Azrakhsh NA, Mohn KGH et al. Covid-19 og venøs tromboembolisme - profylakse og behandling. Tidsskr Nor Legeforen 2020;140. doi: 10.4045/tidsskr.20.0440. [PubMed][CrossRef]

5. Panigada M, Bottino N, Tagliabue P et al. Hypercoagulability of COVID-19 patients in intensive care unit: A report of thromboelastography findings and other parameters of hemostasis. J Thromb Haemost 2020; 18: 1738-42. [PubMed][CrossRef]

6. Thachil J, Tang N, Gando S et al. ISTH interim guidance on recognition and management of coagulopathy in COVID-19. J Thromb Haemost 2020; 18: 1023-6. [PubMed][CrossRef]

7. McFadyen JD, Stevens H, Peter K. The emerging threat of (micro)thrombosis in COVID-19 and its therapeutic implications. Circ Res 2020; 127: 571-87. [PubMed][CrossRef]

8. Chow JH, Khanna AK, Kethireddy S et al. Aspirin use is associated with decreased mechanical ventilation, ICU admission, and in-hospital mortality in hospitalized patients with COVID-19. Anesth 
Analg 2020; 132: 930-41. [PubMed][CrossRef]

9. COVID-19: Patienten haben mit „Low dose"-ASS geringes Komplikations- und Sterberisiko.

Deutsches Ärzteblatt 23.10.2020. https://www.aerzteblatt.de/nachrichten/117689/COVID-19-Patientenhaben-mit-Low-dose-ASS-geringes-Komplikations-und-Sterberisiko Lest 29.6.2021.

10. Mestres G, Puigmacià R, Blanco C et al. Risk of peripheral arterial thrombosis in COVID-19. J Vasc Surg 2O20; 72: 756-7. [PubMed][CrossRef]

11. Bellosta R, Piffaretti G, Bonardelli S et al. Regional survey in Lombardy, Northern Italy, on vascular surgery intervention outcomes during the COVID-19 pandemic. Eur J Vasc Endovasc Surg 2021; 61: 688-97. [PubMed][CrossRef]

12. Bellosta R, Luzzani L, Natalini G et al. Acute limb ischemia in patients with COVID-19 pneumonia. J Vasc Surg 2020; 72: 1864-72. [PubMed][CrossRef]

Publisert: 6. juli 2021. Tidsskr Nor Legeforen. DOI: 10.4045/tidsskr.21.0289

Mottatt 8.4.2021, første revisjon innsendt 9.6.2021, godkjent 29.6.2021.

Publisert under åpen tilgang CC BY-ND. Lastet ned fra tidsskriftet.no 26. april 2023. 